\title{
Fe(III)-Chloroquine Complex: A New Potent Compound in Wellness Industries of High Antimicrobial and Antimalarial Activities
}

\author{
Deepa Thakur ${ }^{1, *}$, Jyotsna Mishra $^{2}$, K.S. Pitre ${ }^{3}$ and Smita Joshi ${ }^{1}$ \\ ${ }^{1}$ Department of Chemistry, Sarojni Naidu Girls P.G. Collage, Bhopal, MP, India \\ ${ }^{2}$ Department of Chemistry, Scope College of Engineering, Bhopal, MP, India \\ ${ }^{3}$ Department of Chemistry, Dr. H.S. Gour University, Sagar, MP, India
}

\begin{abstract}
Fe}(\mathrm{III})$ - Chloroquine complex has been synthesized and screened for its physicochemical, microbial as well as pharmacological activity have been done in solid and aqueous phase. On the basis of elemental analysis, polarographic studies, amperometric titration and IR spectral studies the probable formula for the complex has been determined at $25 \pm 1^{\circ} \mathrm{C}$ and ionic strength of $\mu=1.0[\mathrm{KCl}$. Raper's paper disc method was used for microbial study against various pathogenic bacteria and fungi. In vivo syudy of Swiss mice [25-30gm] were used for antimalarial activity against Chloroquine and its complex on xyline-Alcoholic activity test Kidney, liver and serum of these rats were also studied. On the basis of observed result it could be concluded that Fe (III)-Chloroquine complex were found to be non-toxic and more potent than pure chloroquine drug.
\end{abstract}

Keywords: Fe (III) - Antimicrobial activity, Antimalarial activity, in vivo study.

\section{INTRODUCTION}

Fe(III) Plays a important role in biological system. It involves in transportation of oxygen through hemoglobin. It also play a several other important role in vivo [1]. Antimalarial drugs are used for the treatment of malaria. Most of the work Chloroquine [2] as a ligand has been concerned with its metal complexes [3] in solution and solid state. Present investigation deal with the bio-inorganic study of the interaction of such biological essentially metal. Fe(III) and an antimalarial drug chloroquine changes the biological properties of the pure drug have been evaluated and underlying role of iron in the antimalarial activity of chloroquine has been discussed.

A number of analytical methods for the determination of drugs have been reported in literature [4]. However, formation of the metal complex and its characterizations by polarographic methods which are far better than the existing methods in the field as regards to their extra ordinary detection sensitivity, oligo determination capability, minimum detection limit, low cost, rapidity, accuracy, simplicity and non destructive nature, have not been used for the said purpose.

Several metals such as $\mathrm{Fe}, \mathrm{Co}, \mathrm{Zn}, \mathrm{Cd}$ and $\mathrm{Ni}$ in trace amount are essential for health and for the maintenance of human biological system. The

*Address correspondence to this author at the Department of Chemistry, Sarojni Naidu Girls P.G. Collage, Bhopal, MP, India; Tel: 9752752799;

E-mail: 80dthakur@gmail.com complexes of life essential metals play significant role in biological system, in which enzymes are known to be activated by metal ions. In continuation of the work reported from our laboratory on the study of electrochemical and bioinoganic behavior of some drug and metal-drug complexes [5]. The present paper describes the characterization of $\mathrm{Fe}$ (III)-Chloroquine complex using polarographic and spectral methods. Microbial study and pharmacological study of antibacterial activity have been also reported in the paper.

\section{MATERIALS AND METHODS}

\section{Chemicals and Reagents}

All the chemicals were used of analytical grade and used without further purification. Sigma Laboratory, USA, supplied the anti-malarial drug chloroquine, standard solution of $\mathrm{Fe}(\mathrm{III})(0.01 \mathrm{M})$, Chloroquine $(0.01 \mathrm{M})$ and $\mathrm{KCl} 2 \mathrm{M})$ were prepared in distilled water.

\section{Polarographic Study of $\mathrm{Fe}$ (III)-Chloroquine Complex}

All the polarograms were recorded on Elico (india) DC Polarograph model CL357, Polarographic measurements were made on a polarograph software connected $\Omega$ metrohm 757VA computrance. The polarographic cell consisted of a three electrodes assembly and a stirrer having a dropping mercury electrode [DME] as a working electrode, a platinum wire as an auxiliary electrode and $\mathrm{Ag} / \mathrm{AgCl}$ electrode as reference electrode. The nitrogen gas was bubbled for 
five minutes. Elico digital $\mathrm{pH}$ meter model LI-108 was used to measure the $\mathrm{pH}$ of all test solutions.

Experimental sets were prepared by keeping overall $\mathrm{Fe}$ (III) (metal ion) and $\mathrm{KCl}$ (supporting electrolyte) concentration fixed at $1.0 \mathrm{Mm}$ and $1.0 \mathrm{M}$ respectively. The ligand concentration was varied from 0.01 to 5 $\mathrm{mm}$. The $\mathrm{pH}$ of the test solution was adjusted to $7.0 \pm 0.1$ using $\mathrm{HCl} / \mathrm{NaOH}$ solution.

\section{Amperometric Study of $\mathrm{Fe}(\mathrm{III})$-Chloroquine Complex}

The amperometric titration were performed on a manually operated set up, a polyflex galvanomter and an AJCO varnier potentiometer, a DME was used as an indicator electrode and a calomel electrode served as a reference electrode. The capillary characteristics of a DME had a m ${ }^{2 / 3}, \mathrm{t}^{1 / 6}=2.13 \mathrm{mg}^{2 / 3} \mathrm{sec}^{-1 / 2}$ at $50 \mathrm{~cm}$ effective height of mercury column.

Experimental sets each having different but known amount of the drugs under study were prepared in appropriate quantity of potassium chloride (supporting electrolyte $\mathrm{pH} 7.0 \pm 0.1$ ) and titrated separately against the standard solution of the titled $\mathrm{Fe}$ (III) ions whose $\mathrm{pH}$ has been adjusted to that of titrate.

\section{Synthesis Procedure of $\mathrm{Fe}(\mathrm{III})$-Chloroquine Solid Complex}

Chloroquine and ferric chloride solution were separately prepared and were mixed in 1:1 molar ratio. The mixture was then refluxed in a round bottom flask for 1-2h. The residue complex was filtered and washed thoroughly to remove any unreacted materials. The complex was dried at low temperature $\left(35^{\circ} \mathrm{C}\right)$ and stored over $\mathrm{P}_{4} \mathrm{O}_{10}$.

The IR spectrum of the solid complex was recorded using $\mathrm{KBr}$ pallets on a Perkin Elmer IR Spectrophotometer Model-379.

\section{Biological Activity of Fe(III)- Chloroquine Complex}

\section{Microbial Study}

The Raper's disc method [6] has followed for the microbial screening of the complex against various pathogenic bacteria and fungi viz. Aspergillus flavues, Aspergillus Niger, Escherichia coli, Salmonella typhi Vibreo Colarae and Diplococcs pneumonia sterilized filter paper disc $(6 \mathrm{~mm})$ were dipped into the complex solution of $0.01 \mathrm{~m}$ concentration prior to this, the bacteria and fungi were separately homogenized with nutrient agar and potato dextrose media $\left(27^{\circ} \mathrm{C}\right)$ plated onto the sterilized petri dishes. Dipped filter paper discs were placed on seeded medium. After $24 \mathrm{~h}$ of incubation antimicrobial activities were recorded by measuring the inhibition zone against complex under study. Similar Experiment was repeated with the control drug (Chloroquine).

The percentage inhibition was calculated using the formula

$$
\% \text { Inhibition }=(a-b) / a \times 100
$$

Where 'a' represent diameter of inhabitation zone for control drug and ' $b$ ' represent diameter of inhibition zone for complex. Fe(III)-chloroquine

\section{Pharmacological Studies}

For pharmacological study the Swiss mice were infected by plasmodium bergi. The albino mice were divided into 3 groups and single mice in each group and kept in metal cage and feed with mice cube and water albitum.

Group A-Control

Group B-chloroquine

$$
\text { Group C-[Fe (QUINE) } \left.\mathrm{Cl}_{2} \cdot \mathrm{H}_{2} \mathrm{O}\right] \mathrm{SO}_{4} \cdot 3 \mathrm{H}_{2} \mathrm{O}
$$

The oral dose of the drug solution were prepared in distilled water. These prepared solution administrated orally to mice two times daily on $15,30,45,60$ days. The mice in each group were marked for easy identification. The protocol study of mice were monitored daily by counting the parasite in blood serum fixed with $70 \%$ methanol and Giesnsa stain. This could be due to complex binding first without being decompose at the receptor site and also the deposition of free metal ion in the membrane of the parasite. The result showed the comparison between the ligand [drug] and their complex showed that $\left[\mathrm{Fe}(\mathrm{QUINE}) \mathrm{Cl}_{2} \cdot \mathrm{H}_{2} \mathrm{O}\right] \mathrm{SO}_{4} \cdot 3 \mathrm{H}_{2} \mathrm{O}$ are more active than their respective free ligand.

\section{RESULT AND DISCUSSION}

\section{Polarographic Behavior of Chloroquine with Fe(III)}

Polarographic behavior of chloroquine with $\mathrm{Fe}(\mathrm{III})$ In $1.0 \mathrm{M} \mathrm{KCl}$ at $\mathrm{pH} 7.0 \pm 0.2 \mathrm{Fe}$ (III) and its complex with the ligand under study were found to be reversibly reduced involving three electrons which was evidenced by the plots of $\mathrm{i} /\left(\mathrm{i}_{d-i}\right)$. The reduction was found to be diffusion controlled, which was evidenced by the plot of $\mathrm{i}_{\mathrm{d}}$ Vs. Corr. 
On gradual increase of the chloroquine concentration the half wave potential of $\mathrm{Fe}$ (III) metal ion shifted to more electronegative value and the diffusion current also decreased there by showing complex formation between $\mathrm{Fe}(\mathrm{III})$ with chloroquine. These shows the co-ordination of metal and drug complex enhance the activity of the drug.

To study the composition and formation constant of the complex, plots of $\Delta E_{1 / 2}$ (shift in the $E_{1 / 2}$ ) i.e $\Delta E_{1 / 2}=\left(E_{1 / 2}\right)_{c}-\left(E_{1 / 2}\right)_{s}$ against log $C_{X}$ ( logarithm of the concentration of the ligand) were drawn. The plots were linear lines showing the formation of single complex species in solution Lingan's treatment [7] of the observed polarographic data reveals $1: 1$ metal chloroquine complex with formation constant $10 \mathrm{~g}$ $\beta=4.5$.

\section{Amperometric Determination of Chloroquine with $\mathrm{Fe}(\mathrm{III})$}

$\mathrm{Fe}$ (III) gives a well defined polarographic wave in $1.0 \mathrm{M} \mathrm{KCl}$ at $\mathrm{pH} 7.0 \pm 0.2$. The diffusion current was found proportional to the concentration of $\mathrm{Fe}(\mathrm{III})$. The chloroquine drug does not produce any wave under the said experimental conditions. The plateau potential for the polarographic wave of $\mathrm{Fe}(\mathrm{III})(-1.4 \mathrm{~V})$ vs $\mathrm{Hg}$ pool was applied for carrying out amperometric titration. On performing the amperometric titration of drug solution with standard solution of $\mathrm{Fe}(\mathrm{III})$, the current volume plots resulted in $\mathrm{V}$ shaped curve (Figure 1). The end point as located by graphical method revealed metal to drug ratio of $1: 1$, which is in agreement with the author's observation on the metal: ligand equilibria using polarographic method.

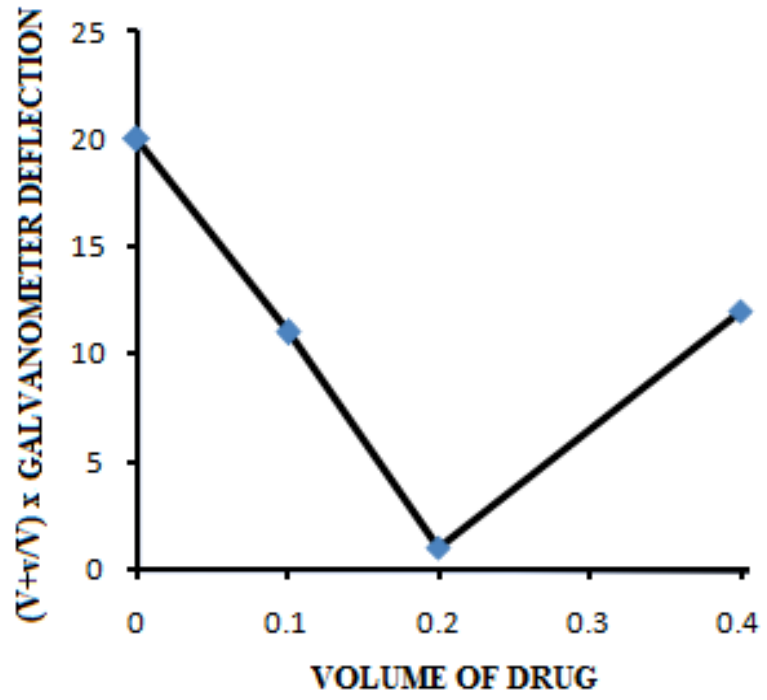

Figure 1: Amperometric titration of $(2 \mathrm{mM} / 10 \mathrm{ml})$ Chloroquine $(1 \mathrm{mM} / 10 \mathrm{ml}) \mathrm{Fe}(\mathrm{III})$ solution.

\section{Characterization of $\mathrm{Fe}(\mathrm{III})$ - Chloroquine Complex}

The IR data (Table 1) corresponds to the result of the most informative and indicative region. The assignment been based on literature value obtained for similar structural compound. In general, the metal complex [9] show very broad band between 3600-3000 $\mathrm{cm}^{-1}$. Which are assigned to the $\cup(\mathrm{OH})$ of water molecule or hydrogen bonding. A moderates and medium band obtained at 3247.2 and $3217.0 \mathrm{~cm}^{-1}$ in the studied spectral region of the free ligands which are found shifted in the complexes is due to the $u(\mathrm{NH})$ of the dimethyl amino group of the compounds indication the involvement of $\mathrm{N}-\mathrm{H}$ of the ligand in the co ordination with the metal [8]. The frequencies observed at 1380 and $1374 \mathrm{~cm}^{-1}$ in the free ligand, which has undergone a shift in the metal complex, indicates bonding of the ligand to the metal. The shift in frequencies of the bands of the complexes to those of the ligands and denotes the change in the vibrational status upon complexation to the metal ion.

Table 1: Principal IR Frequencies for Chloroquine and its Complex ( $w=w e a k, b=b r o a d, m=$ medium spectrum)

\begin{tabular}{|c|c|c|c|}
\hline $\begin{array}{c}\text { Ligand / } \\
\text { complex }\end{array}$ & $v(\mathrm{OH}) \mathbf{c m}^{-1}$ & $v(\mathbf{N H}) \mathbf{c m}^{-1}$ & $v(\mathrm{C}=\mathrm{N}) \mathbf{c m}^{-1}$ \\
\hline \hline Chloroquine & $3454.0 \mathrm{w}, \mathrm{b}$ & $3217.0 \mathrm{w}, \mathrm{b}$ & $1374.2 \mathrm{~m}$ \\
\hline $\begin{array}{c}\mathrm{Fe}(\mathrm{QUINE})\left(\mathrm{H}_{2} \mathrm{O}\right) \\
\mathrm{SO}_{4} .3 \mathrm{H}_{2} \mathrm{O}\end{array}$ & $3368.0 \mathrm{w}$ & $3247.3 \mathrm{w}$ & $1372.5 \mathrm{w}$ \\
\hline
\end{tabular}

On the basis of above data a tentative structure of the $\mathrm{Fe}(\mathrm{III})$ - Chloroquine complex [9] may be given as structure in (Figure 2).

\section{Antimicrobial Study of Chloroquine Fe(III) Complex}

The in vitro biological screening effects of the investigated compounds were tested against four bacterial strain such as Aspergillus flavues, Aspergillus Niger, Escherichia coli, Salmonella typhi Vibreo Colarae and Diplococcs pneumonia. The antibacterial activity minimum inhabitation concentrations (MIC)values of the novel investigation compound against the growth of organisms are summarized in Table 3. A relative study of ligand and their metal complexes exhibit higher antibacterial activity than uncomplexed ligands. The result are promising compare with the previous studies. Such increased activity of the overtone concept and chelation theory. According to the overtone of cell permeability, the lipid membrane that surrounds the favors the passage of 


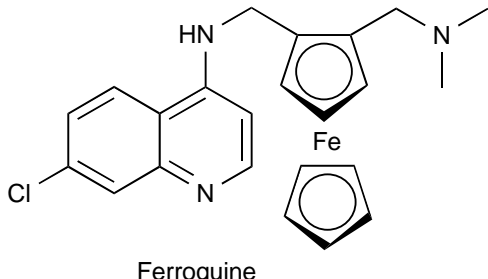

Ferroquine

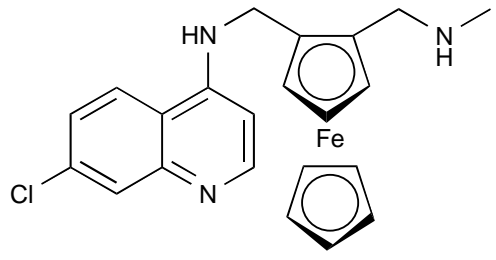

Ferroquine metabolite

Figure 2: Ferroquine complex.

Table 2: Antimicrobial Results of Fe(III)-Choloroquine

\begin{tabular}{|c|c|c|c|}
\hline Organism & Complex & Control (a) & \% Inhibition Zone \\
\hline \hline Aspergillus flavues & 40 & 38 & $65 \%$ \\
\hline Aspergillus Niger & 45 & 40 & $55 \%$ \\
\hline Escherichia Coli & 35 & 33 & $58 \%$ \\
\hline Salmonella Typhi & 42 & 31 & $68 \%$ \\
\hline Vibreo Cholera & 32 & 30 & $64 \%$ \\
\hline Diplococcs Pneumonia & 36 & 29 & $60 \%$ \\
\hline
\end{tabular}

only lipid-soluble material in which liposolublity is an important factors that control the antimicrobial activity. On chelation the polarity of the metal ion will be reduced to a greater extent due to overlap of ligand orbital and partial sharing of the positive charge of the metal ion with donor groups. Further it increase the deloclization of II electron over the whole chelate ring and enhance the lipophilicity the penetration of complexes into the lipid membranes and block the binding site in enzymes of microorganism. These complexes also disturb the respiration process of the cell and thus block the synthesis of protein, which restrict further growth of the organism.

\section{Antimalerial Screening}

Swiss mice for experiment was injected as describe by Sanchey - Delgado et al. The mice were divided into 3 groups and keep 1 mice in each group

Group A - Control

Group B - Chloroquine complex

Group C - Fe (QUINE) $\mathrm{Cl}_{2} \mathrm{H}_{2} \mathrm{O}$ ) $\mathrm{So}_{4} 3 \mathrm{H}_{2} \mathrm{O}$

The drug solution prepared with DMSO were administered orally to the mice, two times daily for 15 days, 30 days, 45 days, 60 days at a dosage level 0.64 $\mathrm{mg} / 150 \mathrm{~g}$ for drug. The mice in each group were marked for easy identification. The mice were inoculated intravenously with $0.2 \mathrm{~m}$ of $1 \times 10^{6}$ parasitized erythrocytes suspended in buffered physiological saline $(\mathrm{pH} 7.4)$. The mice were left for 15 days interval of each dosing and their levels of parasitaemias [10] were monitored daily by counting parasites in blood serum, fixed with $70 \%$ methanol and Giemsa stain the slide were viewed under the microscope with magnification of 100 . The level of parasitaemia was then determined by counting the number of injected erythrocyte / 1000 erythrocytes in tail bloods serum stained with Giemsa Stain.

$1.0 \mathrm{ppm}$ of solution of each of the ligand and complex was prepared $0.4 \mathrm{ml}$ each of the solution was injected daily into the each mice of group and their level of parasitaemia was determined on 15 days of intervals. Only Physiological Saline solution was given to the control animals. The percentage of injected cell or inhibition of parasite calculated from the equation-

$\%$ of inhibition $=100$ - estimated number of parasite treated mice

Estimated the number of parasite in untreated mice

The protocol study of histropathalogical effect of oral administration of the ligand and the complex on rat kidney, liver and serum by xylin - alcoholic test showed in Table 3. The serum xylin-alcoholic test shown slight significant change $(P<0.05)$. On comparison with one another and the control after repeated administration of ligand and complex. The fact that their has slight significant change in serum xyline - alcoholic test of ligand and ligand metals complex administrator rats when compared with control suggested that the integrity of the plasma membrane has not compromised.

Moreover observed significant increase in the xyline - Alcoholic test of the liver and kidney of rates 
Table 3: Effect of Administration of Some Drug Metal Complexes on Activity of, Kidney, Liver and Serum

\begin{tabular}{|c|c|c|c|}
\hline Ligand/ complexes & Kidney JU/L & Liver JU/L & Serum JU/L \\
\hline \hline Control & $64.19 \pm 5.11$ & $20.03 \pm 1.90$ & $10.6 \pm 0.96$ \\
\hline Chloroquine & $72.40 \pm 6.09$ & $7.14 \pm 2.15$ & $10.00 \pm 8.88$ \\
\hline$\left[\mathrm{Fe}(\mathrm{QUINE}) \mathrm{Cl}_{2} \mathrm{H}_{2} \mathrm{O}\right] \mathrm{SO}_{4} .3 \mathrm{H}_{2} \mathrm{O}$ & $80.40 \pm 0.83$ & $30.42 \pm 2.73$ & $8.76 \pm 0.57$ \\
\hline
\end{tabular}

Table 4:

\begin{tabular}{|c|c|c|c|c|}
\hline Drug & No. & $\begin{array}{c}\text { Average \% } \\
\text { parasitaemia in mice } \\
\text { before administration }\end{array}$ & $\begin{array}{c}\text { Average \% parasitemia after } \\
\text { administration }\end{array}$ & $\begin{array}{c}\text { Average \% reduction in } \\
\text { parasitaemia after } \\
\text { administration }\end{array}$ \\
\hline \hline Chloroquine & C & 40 & 8 & $68 \%$ \\
\hline$\left[\mathrm{Fe}(\mathrm{QU} I N E) . \mathrm{Cl}_{\mathrm{H}} \mathrm{O}\right] \mathrm{SO}_{4} .3 \mathrm{H}_{2} \mathrm{O}$ & $\mathrm{Q} 1$ & 41 & 2 & $95 \%$ \\
\hline
\end{tabular}

administrators with chloroquine complex suggests an enhancement of the activities of the enzyme by the drug and its metabolites the increase may also be as a result of stress imposed on the tissue by the drug which may lead to loss of the tissues by the drug which may lead to loss of the enzyme molecule through leakage into extra cellular fluid which has not been significantly notice in the serum [11]. In a bid to offset this stress the tissue may increase the de-novo synthesis of the enzyme thus accounting for the increase the xyline -Alcoholic activity test.

Table 4 shows that anti malarial activity of quinine ligand is more pronounced in parasitism are 68\%. $94 \%$ for chloroquine respectively.

\section{ACKNOWLEDGEMENT}

The authors are thankful to Head, Department of Chemistry, Dr. Hari Singh Gour University, Sagar for providing necessary laboratory facilities.

\section{REFERENCE}

[1] Hubel, RK, Polborn and WC Beek. Cincona alkaloids as versatile Ambivalent ligands co-ordination of transition metal to the four potential donar sites of Quinine. Eur J Inorg Chem 1999; 471-82.

http://dx.doi.org/10.1002/(SICI)1099-

0682(199903)1999:3<471::AID-EJIC471>3.0.CO;2-H

[2] Brot CLA, Delnacs L, Macie JS, Mortuaire M, Camus D, Dive $D$, et al. Synthetic ferrocinic mefloquine and Quinine analogues potential antimalerial agents. Eur $\mathrm{J}$ Med Chem 2000; 35: 707-14.

http://dx.doi.org/10.1016/S0223-5234(00)00178-1

[3] Ferrari MB, Biscegliea F, Favaa GG, et al. Synthesis, characterization and biological activity of two new polymeric copper(II) complexes with aketoglutaric acid thiosemicarbazone. J Inorg Biochem 2002; 89: 36-40. http://dx.doi.org/10.1016/S0162-0134(01)00371-3

[4] Bassett J, Denny RC, Jeffery GH, et al. Vogel's Text Book of Quantitative Analysis, ELBS $4^{\text {th }}$ Ed, Londan 1978; 130. http://pubs.acs.org/doi/abs/10.1021/J0025792P

[5] Shukla J, Pitre KS. Role of Biometal Fe(III) in anticancer effect of Dacarbazine 1998; 42(2): 223 www.ijpp.com/IJPP\%20archives/1998_42_2/223-230.

[6] Bauer AW, Kirby WMM, Sherris JC, et al. Antibiotic Susceptibility testing by standardized single disk method. Am J Clin Pathol 1966; 36: 493-96. http://dx.doi.org/10.4314/ahs.v12i2.9

[7] Lingane JJ. Interpretation of the Polarographic Waves of Complex Meta Ions. Chem Rev 1941; 29(1): 1-35. http://dx.doi.org/ 10.1021/cr60092a001

[8] Crow DR, Westwood JV. Polarography of metal complexes; Academic press London 1969; 56.

[9] Nakamoto K. Infrared and Raman spectra of inorganic and coordination compound, $3^{\text {rd }}$ Ed.Willey, Inter Sc Pub, New York 1977; p. 313.

[10] Nadira W, Singh HB. Synthesis of Metal complexes of antimalarial drugs and in-vitro evaluation of their activity against Plasmodiam falcipharum. Inorg Chim Acta 1987; 135: 134-37. http://dx.doi.org/10.1016/S0020-1693(00)83271-6

[11] Glans L, Ehnbom A, de Kock C, Martínez A, Estrada J, Smith PJ, et al. Ruthenium II arene complex with chelatingchloroquine analogue ligands: synthesis, characterization and in vitro antimalarial activity. Dalton trans.2012; 41: 27642773.

http://dx.doi.org/10.1039/C2DT12083F

Received on 17-02-2013

\section{DOI: http://dx.doi.org/10.6000/1927-3037.2013.02.03.5}

(C) 2013 Thakur et al.; Licensee Lifescience Global.

This is an open access article licensed under the terms of the Creative Commons Attribution Non-Commercial License (http://creativecommons.org/licenses/by-nc/3.0/) which permits unrestricted, non-commercial use, distribution and reproduction in any medium, provided the work is properly cited. 